\title{
Azithromycin Suppresses Activation of Nuclear Factor-kappa B and Synthesis of Pro-inflammatory Cytokines in Tracheal Aspirate Cells From Premature Infants
}

\author{
ZUBAIR H. AGHAI, ARUNA KODE, JUDY G. SASLOW, TAREK NAKHLA, SABEENA FARHATH, GARY E. STAHL, \\ RIVA EYDELMAN, LOUISE STRANDE, PAOLA LEONE, AND IRFAN RAHMAN
}

Department of Pediatrics [Z.H.A., J.G.S., T.N., S.F., G.E.S.], Department of Surgery [R.E., L.S., P.L.], Cooper University Hospital-Robert Wood Johnson Medical School, Camden, New Jersey 08103; Department of Environmental Medicine [A.K., I.R.], Lung Biology and

Disease Program, University of Rochester Medical Center, Rochester, New York 14642

\begin{abstract}
Nuclear factor-kappaB (NF- $\kappa$ B) plays a central role in regulating key proinflammatory mediators. The activation of NF- $\kappa \mathrm{B}$ is increased in tracheal aspirate (TA) cells from premature infants developing bronchopulmonary dysplasia (BPD). We studied the effect of azithromycin (AZM) on the suppression of NF- $\kappa$ B activation and the synthesis of pro-inflammatory cytokines IL- 6 and IL- 8 by TA cells obtained from premature infants. Tracheal aspirate cells were stimulated with tumor necrosis factor-alpha (TNF- $\alpha$ ) and incubated with AZM. The nuclear NF- $\kappa$ B-DNA binding activity, the levels of inhibitory kappaB-alpha $(\mathrm{I} \kappa \mathrm{B}-\alpha)$ in the cytoplasmic fraction and IL-6 and IL- 8 release in the cell culture media were measured. Stimulation of TA cells by TNF- $\alpha$ increased the activation of NF- $\kappa$ B, which was suppressed by the addition of AZM. Increased activation of NF- $\kappa$ B was also associated with increased levels of pro-inflammatory cytokines (IL-6 and IL-8). AZM significantly reduced the IL-6 and IL-8 production to the levels similar to control. TNF- $\alpha$ stimulation also increased the degradation of $\mathrm{I} \kappa \mathrm{B}-\alpha$, which was restored with the addition of AZM. Our data suggest that AZM therapy may be an effective alternative to steroids in reducing lung inflammation and prevention of BPD in ventilated premature infants. (Pediatr Res 62: 483-488, 2007)
\end{abstract}

$\mathrm{N}^{\mathrm{u}}$ clear factor-kappaB $(\mathrm{NF}-\kappa \mathrm{B})$ is a family of DNAbinding proteins that are required for the transcription of key pro-inflammatory mediators (1-4). In unstimulated cells, $\mathrm{NF}-\kappa \mathrm{B}$ is found in the cytoplasm as an inactive, non-DNA binding form complexed with the inhibitor protein inhibitory kappa $\mathrm{B}(\mathrm{I} \kappa \mathrm{B})(1-4)$. The binding of NF- $\kappa \mathrm{B}$ with anchoring protein $\mathrm{I} \kappa \mathrm{B}$ prevents its translocation into the nucleus. Stimulation of the cells by cytokines IL- $1 \beta$, tumor necrosis factoralpha (TNF- $\alpha$ ), and reactive oxygen species (ROS) leads to the activation and translocation of NF- $\kappa \mathrm{B}$ into the nucleus (1-4). Activated NF- $\kappa \mathrm{B}$, after its translocation into the nucleus, binds with promoter regions of the target genes and

Received February 21, 2007; accepted May 22, 2007

Correspondence: Zubair Aghai, M.D., Cooper University Hospital, UMDNJ 755 Dorrance Bldg,. One Cooper Plaza, Camden, NJ 08103; e-mail: aghai-zubair@ cooperhealth.edu

Supported by the NIEHS EHSC grant ESO1247 (AK and IR).

This work was supported by the grant from American Lung Association of New Jersey.

This study was presented at the Eastern Society of Pediatric Research Meeting (Philadelphia, PA, March 2007) and at the Annual Meeting of Society of Pediatric Research, Toronto, Canada, May 2007. increases the transcription of inflammatory mediators. NF- $\kappa \mathrm{B}$ plays an important role in the pathogenesis of acute lung inflammation $(1,2)$. NF- $\kappa \mathrm{B}$ regulates gene expression of proinflammatory cytokines, chemokines, and adhesion molecules (1). In adults with acute respiratory distress syndrome, enhanced activation of NF- $\kappa \mathrm{B}$ was detected in alveolar macrophages recovered by bronchoalveolar lavage (5). NF- $\kappa \mathrm{B}$ is also expressed in alveolar macrophages of mechanically ventilated preterm neonates (6). Recently, a study has shown that the activation of NF- $\kappa \mathrm{B}$ is increased in tracheal aspirates (TA) cells of preterm infants who developed bronchopulmonary (BPD) (7). Thus, it appears that the activation of NF- $\kappa \mathrm{B}$ is central to the development of pulmonary inflammation and lung injury. Since NF- $\kappa$ B activation is a regulated process in the very early steps of lung inflammation, NF- $\kappa \mathrm{B}$ is an obvious target for anti-inflammatory treatment.

Recently, we reported that dexamethasone inhibits the activation of NF- $\kappa \mathrm{B}$ in tracheal aspirate cells from premature ventilated infants and suppresses NF- $\kappa \mathrm{B}$ dependent proinflammatory mediators (8). However, the use of steroids in premature neonates has deleterious effects on brain development and is associated with developmental delay and cerebral palsy $(9,10)$. In its policy statement, the American Academy of Pediatrics (AAP) discourages the use of steroids in premature infants (11). Therefore, studies are needed to find a safer alternative to steroids in the prevention of BPD in preterm infants. Azithromycin (AZM) is a macrolide antibiotic known for its immunomodulating and anti-inflammatory properties. However, the role of AZM in suppressing pro-inflammatory mediators in the lungs of premature infants is not known.

The objective of this study was to evaluate the effect of AZM on the activation of NF- $\kappa \mathrm{B}$ and the synthesis of cytokines (IL-6 and IL-8) by TA cells from premature infants. We hypothesized that AZM suppresses the activation of NF- $\kappa \mathrm{B}$, which is associated with decreased release of pro-inflammatory mediators by tracheal aspirate cells from premature infants.

Abbreviations: AZM, azithromycin; BPD, bronchopulmonary dysplasia; $\mathbf{I} \boldsymbol{\kappa} \mathbf{B}-\boldsymbol{\alpha}$, inhibitory kappa B-alpha; NF- $\mathbf{B}$, nuclear factor-kappaB; TA, tracheal aspirates 


\section{DESIGN AND METHODS}

Study population. The study was conducted in a 39 bed, level III Neonatal Intensive Care Unit (NICU) at the Cooper University Hospital in Camden, NJ, between June 2005 and December 2006. The Institutional Review Committee approved this study and parents signed a written informed consent. Relevant clinical data were collected from the patient's chart.

Tracheal aspirate cells $(n=11)$ were obtained from 10 ventilated preterm infants. The TA was collected by instilling $0.5 \mathrm{~mL}$ of normal saline into the infant's endotracheal tube and suctioning the residue with a 5-F suction catheter after two or three ventilator breaths. The suction catheter was passed to a standardized length of $0.5-1 \mathrm{~cm}$ beyond the tip of the endotracheal tube. The procedure was repeated two to three times. The suction catheter was flushed with $0.5 \mathrm{~mL}$ of normal saline after each suctioning episode to collect the residual sample in the catheter. The samples were transported to the laboratory on ice and immediately processed. The cells were counted using a hemocytometer and a viability test was performed using trypan blue. TA samples with more than 4 million cells and viability of $98-100 \%$ were used for the study.

Differential cell count. Hematoxylin and eosin (H \& E) staining was performed on cytospin slides prepared from the TA cells. A differential cell count was conducted by counting cells in four different fields and calculating the percentages of polymorphonuclear, macrophage, lymphocyte and epithelial cells.

TA cells isolation and culture. Tracheal aspirate samples were centrifuged at $4^{\circ} \mathrm{C}$ for $10 \mathrm{~min}$ at $300 \mathrm{~g}$. The cell pellet was resuspended in four polypropylene tubes using RPMI 1640 media supplemented with $15 \%$ bovine growth serum and allowed to equilibrate in the incubator for $15 \mathrm{~min}$ at $37^{\circ} \mathrm{C} / 5 \% \mathrm{CO}_{2}$ with gentle agitation. TA cells were incubated in four groups (one million cells per group). Tube 1 was used for a control (C group). Tubes $2-4$ were stimulated with TNF- $\alpha$ ( $2 \mathrm{ng} / \mathrm{mL})$. Tube 2 was the TNF- $\alpha$ control (TNF). A low dose of AZM ( $4 \mu \mathrm{g} / \mathrm{mL}$ ) was added to Tube 3 (4 AZM group) and a high dose of azithromycin $(8 \mu \mathrm{g} / \mathrm{mL})$ was added to Tube 4 (8 AZM group). All tubes were incubated at $37^{\circ} \mathrm{C} / 5 \% \mathrm{CO}_{2}$, with gentle agitation for $18 \mathrm{~h}$. After incubation, the supernatant from each tube was collected, aliquoted, and stored at $-70^{\circ} \mathrm{C}$ for analysis of IL-6 and IL-8. Nuclear and cytoplasmic proteins were extracted from the cell pellets as described below.

Nuclear and cytoplasmic protein extraction. As per the manufacturer's instructions, nuclear and cytoplasmic proteins were extracted from the cell pellet by using a commercially available kit (Active Motif, Carlsbad, CA). Briefly, the cell pellet was resuspended in hypotonic buffer and incubated on ice for $15 \mathrm{~min}$. Twenty-five microliters of detergent was added and the suspension was centrifuged $(14,000 \mathrm{~g})$ for $30 \mathrm{~s}$ at $4^{\circ} \mathrm{C}$. The supernatant (cytoplasmic fraction) was stored at $-70^{\circ} \mathrm{C}$ for future analysis. The nuclear pellet was resuspended in complete lysis buffer and incubated for $30 \mathrm{~min}$ on ice on a rocking platform set at $150 \mathrm{~g}$. The suspension was centrifuged for 10 $\min (14,000 \mathrm{~g})$ at $4^{\circ} \mathrm{C}$. The supernatant (nuclear extract) was aliquoted and stored at $-70^{\circ} \mathrm{C}$. The total protein concentration was measured in the cytoplasmic and nuclear extract by the Bradford assay (Bio-Rad, Richmond, CA).

Western blot analysis for IKB- $\alpha$. Twenty micrograms of isolated cytosolic protein from each group was analyzed by SDS-PAGE and transferred onto a nitrocellulose membrane (Amersham, Arlington Heights, IL) using an electroblotting technique. The nitrocellulose membrane was blocked with $10 \%$ nonfat dry milk for $1 \mathrm{~h}$ at room temperature, and subsequently incubated with goat polyclonal I $\kappa \mathrm{B}-\alpha$ (Santa Cruz Biotechnology Inc., Santa Cruz, CA) $1: 1000$ in $5 \%$ nonfat dry milk overnight at $4^{\circ} \mathrm{C}$. After three washing steps of $15 \mathrm{~min}$ each, I $\kappa \mathrm{B}-\alpha$ protein levels were detected using a rabbit anti-goat antibody $(1: 20,000)$ linked to horseradish peroxidase (Jackson Immunology Research, West Grove, PA), and bound complexes were detected using an enhanced chemiluminescence method (ECL, Jackson Immunology Research, West Grove, PA). The relative intensity of the bands was quantified by densitometry using the NIH ImageJ software (http://rsb.info.nih.gov/ij/).

Electrophoretic mobility shift assay. Electrophoretic mobility shift assay (EMSA) was performed using commercially available NF- $\kappa$ B oligonucleotide [5'-AGT TGA GGG GAC TTT CCC AGG C-3', 3'-TCA ACT CCC CTG AAA GGG TCC G-5' obtained from Promega (Madison, WI)]. A labeling reaction was performed with NF- $\kappa$ B-specific double-stranded oligonucleotide with $\left[\gamma_{-}{ }^{32} \mathrm{P}\right]$ ATP. Binding experiments were performed with $10 \mu \mathrm{g}$ of nuclear protein, $2 \mu \mathrm{L}$ of $5 \times$ binding buffer [50 mM HEPES, $\mathrm{pH} 7.5,500 \mathrm{mM}$ $\mathrm{NaCl}, 25 \%$ glycerol, $5 \mathrm{mM}$ EDTA, $0.25 \mathrm{mg} / \mathrm{mL}$ poly (dI-dC) - poly (dI-dC)], and $1 \mu \mathrm{L}$ of the radiolabeled NF- $\kappa \mathrm{B}$-specific oligonucleotide for $20 \mathrm{~min}$ at room temperature. Nondenaturing $8 \%$ PAGE was performed with $0.5 \times$ Tris borate-EDTA buffer, $\mathrm{pH} 8.0$ for $4 \mathrm{~h}$ at $100 \mathrm{~V}$. The gel was dried for $30 \mathrm{~min}$, after which the autoradiography was carried out. To monitor the specificity of the binding reaction, the assay was performed in the presence of 100 -fold molar excess of the nonlabeled NF- $\kappa \mathrm{B}$ oligonucleotide (specific competitor),
Table 1. Clinical characteristics of the subject population $(n=10)$

$\begin{array}{lc}\text { Birth weight }(\mathrm{g}) & 707 \pm 133 \\ \text { Gestational age (wk) } & 25.4 \pm 1.8 \\ \text { Male sex }(\%) & 4(40) \\ \text { Race, black }(\%) & 7(70) \\ \text { Prenatal steroids }(\%) & 8(80) \\ \text { Surfactant doses } & 1.4 \pm 0.4 \\ \text { Days on ventilator } & 46 \pm 32 \\ \text { Days on oxygen } & 97 \pm 48 \\ \text { BPD at 36 wk PMA }(\%) & 5(50)\end{array}$

Values are expressed as mean \pm SD. PMA, postmenstrual age.

unlabeled AP-1 oligonucleotide (nonspecific competitor), negative water control, and a positive HeLa nuclear extract control according to manufacturer's instructions (Promega). The relative intensity of the bands was quantified by densitometry using the ImageJ software.

Pro-inflammatory cytokine assay. Levels of pro-inflammatory cytokines (IL-6 and IL-8) in cell culture supernatants were measured using an ELISA employing a biotin-streptavidin-peroxidase detection system with the respective duo antibody kits (R\&D Systems Inc., Minneapolis, MN) according to the manufacturer's instructions. Each sample was assayed in triplicate and the values were expressed as the mean of eleven experiments.

Statistical analysis. Statistical analysis of significance was calculated using the one-way ANOVA followed by Tukey's posthoc test for multigroup comparisons using STATVIEW and Sigma Chemical Co. plot statistical packages. The results were presented as the mean \pm SEM of the 3 to 11 independent experiments ( $n=11$ for cytokine assay, $n=3$ for Western blots, and $n=7$ for EMSA). The difference was considered significant for $p<0.05$.

\section{RESULTS}

Eleven tracheal aspirate samples for incubation were collected from 10 premature infants. Clinical characteristics of the study population are summarized in Table 1 . The median age of collecting TA cells was $21 \mathrm{~d}$ (range, 9 to $41 \mathrm{~d}$ ). None of the infants received steroids before or at the time of TA samples collection.

Differential cell count in TA samples. The differential cell count was done on each TA sample and expressed as the percentage of total cells. The predominant cells were polymorphs (48\%) and alveolar macrophages (43\%) (Table 2).

AZM inhibited TNF- $\alpha$ induced NF- $\kappa B-D N A$ binding activity in TA cells isolated from preterm infants. We studied the dose dependent inhibitory effect of AZM on basal and TNF- $\alpha$ stimulated NF- $\kappa$ B activation in TA cells isolated from preterm infants. Stimulation of TA cells by TNF- $\alpha$ increased the NF- $\kappa$ B-DNA binding activity by three folds [relative intensity (RI) increased from $1.0 \pm 0.09$ to $3.1 \pm$ $0.2, p<0.001]$. The addition of $4 \mu \mathrm{g} / \mathrm{mL}$ of AZM was not effective in reducing the NF- $\kappa$ B-DNA binding activity (RI decreased from $3.1 \pm 0.2$ to $2.7 \pm 0.18, p=0.17$ ) (Fig. $1, A$ and $B$ ). However, increasing the concentration of AZM to 8 $\mu \mathrm{g} / \mathrm{mL}$ suppressed the TNF- $\alpha$ stimulated activation of NF- $\kappa$ B

Table 2. Differential cell count expressed as percent of total cells in $T A$

\begin{tabular}{cc}
\hline TA cells & Percentage \\
\hline Polymorphs (\%) & $48.0 \pm 13.4$ \\
Macrophage (\%) & $43.0 \pm 12.7$ \\
Lymphocytes (\%) & $8.0 \pm 4.7$ \\
Epithelial cells (\%) & $1.0 \pm 0.7$ \\
\hline
\end{tabular}

Values are expressed as mean $\pm \mathrm{SD}, n=10$. 
A
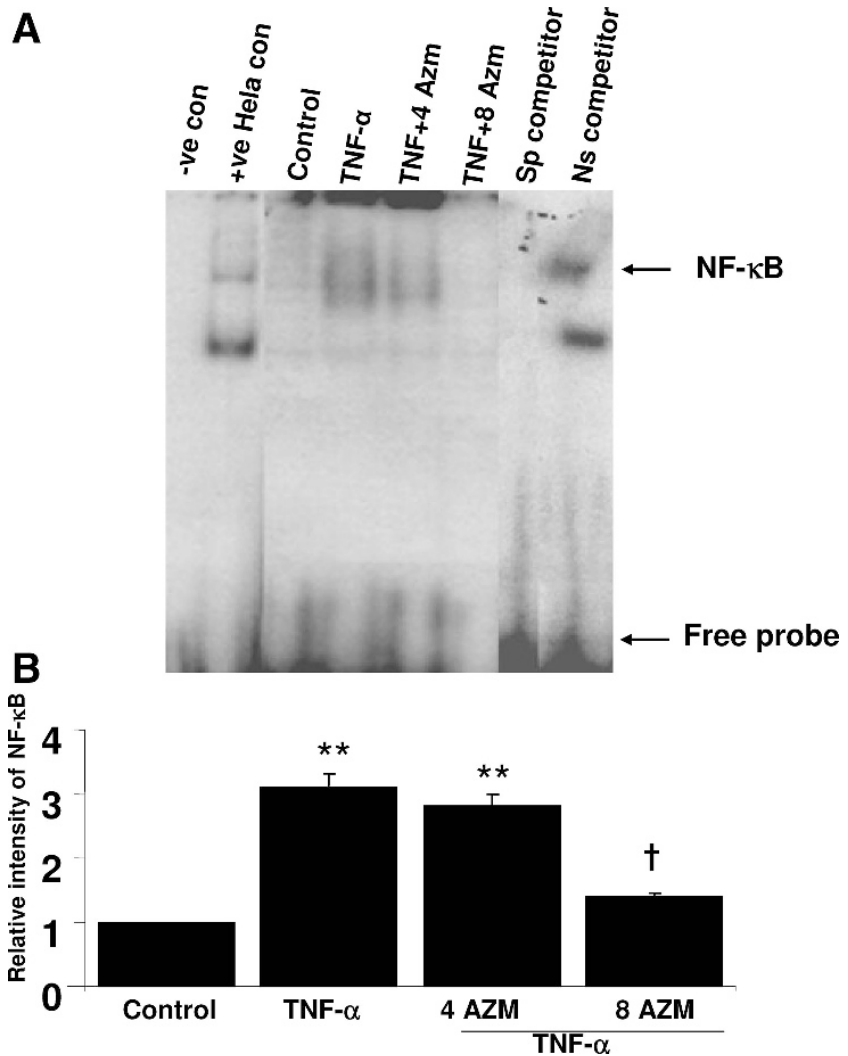

Figure 1. AZM inhibited TNF- $\alpha$ induced NF- $\kappa$ B-DNA binding activity in TA cells from premature infants. (A) NF- $\kappa$ B-DNA binding activity was measured by gel electrophoretic mobility shift assay (EMSA) using commercially available NF- $\kappa$ B oligonucleotide. Stimulation of TA cells with TNF- $\alpha$ $(2 \mathrm{ng} / \mathrm{mL})$ increased NF- $\kappa$ B binding activity $(p<0.001)$. Low dose of AZM $(4 \mu \mathrm{g} / \mathrm{mL})$ did not decrease the NF- $\kappa \mathrm{B}$ binding activity $(p=0.17$ when compared with TNF- $\alpha$ group). However, a higher dose $(8 \mu \mathrm{g} / \mathrm{mL})$ of AZM decreased the NF- $\kappa$ B-DNA binding activity to a level similar to the unstimulated cells ( $p<0.001$ when compared with TNF- $\alpha$ group). The specificity of $\mathrm{NF}-\kappa \mathrm{B}$ signals was determined by cold/specific and nonspecific competitor reactions using specific (NF- $\kappa \mathrm{B})$ and a nonspecific (AP-1) oligonucleotides. Positive and negative control reactions were also performed by using $\mathrm{HeLa}$ nuclear extracts and water, respectively. (B) Histogram is a representative of seven separate experiments (mean $\pm \mathrm{SEM}$ ). ${ }^{* *} p<0.001$ compared with control group and $\dagger p<0.001$ compared with TNF- $\alpha$ treatment group. SP: Specific competitor; NS: Nonspecific competitor.

by approximately $52 \%$ (RI decreased from $3.1 \pm 0.2$ to $1.5 \pm$ $0.12, p<0.001)$. To monitor whether the shifted bands were specific for NF- $\kappa \mathrm{B}$, competition tests were performed by adding nonlabeled NF- $\kappa$ B oligonucleotide (cold/specific competitor) or AP1 oligonucleotide (nonspecific competitor) to HeLa nuclear extracts. Our results showed that the observed $\mathrm{NF}-\kappa \mathrm{B}$ specific signals disappeared in the presence of the cold $\mathrm{NF}-\kappa \mathrm{B}$ competitor but appeared in the presence of the nonspecific competitor.

AZM inhibited TNF- $\alpha$ induced degradation of IאB- $\alpha$ in TA cells of preterm infants. In this study, treatment of TA cells with TNF- $\alpha$ showed increased degradation of I $\kappa \mathrm{B}-\alpha$ in the cytoplasm extracts measured by immunoblotting (Fig. 2). The low dose of AZM $(4 \mu \mathrm{g} / \mathrm{mL})$ was unable to prevent the degradation of I $\kappa \mathrm{B}-\alpha$, but the higher dose of AZM $(8 \mu \mathrm{g} / \mathrm{mL})$ restored the level of I $\kappa \mathrm{B}-\alpha$ in TNF- $\alpha$ stimulated TA cells (Fig. 2).


Figure 2. AZM inhibited TNF- $\alpha$ stimulated degradation of $\mathrm{I} \kappa \mathrm{B}-\alpha$ in TA cells from premature infants. (A) Degradation of $\mathrm{I} \kappa \mathrm{B}-\alpha$ in cytoplasmic extract from TA cells was assessed by Western blot analysis. Stimulation of TA cells after $18 \mathrm{~h}$ of incubation with TNF- $\alpha(2 \mathrm{ng} / \mathrm{mL})$ increased degradation of $\mathrm{I} \kappa \mathrm{B}-\alpha$ $(p<0.001$ when compared with control group), which was restored when the cells were treated with $8 \mu \mathrm{g} / \mathrm{mL}$ of AZM ( $p<0.001$ when compared with TNF- $\alpha$ group). (B) Histogram is expressed as relative intensity of mean \pm SEM of I $\kappa \mathrm{B}-\alpha$ protein bands. ** $p<0.001$ compared with control group and $\dagger p<0.001$ compared with TNF- $\alpha$ treatment group, $n=3$.

TNF- $\alpha$ induced pro-inflammatory cytokine (IL-6 and $I L-8)$ release was suppressed dose-dependently by AZM in TA cells of preterm infants. Stimulation of TA cells by TNF- $\alpha$ increased the levels of IL- 6 from $122 \pm 6.9 \mathrm{pg} / \mathrm{mL}$ to $309 \pm 18.0 \mathrm{pg} / \mathrm{mL}(p<0.001)$ (Fig. 3). Similarly, the levels of IL-8 increased from $175 \pm 5.4 \mathrm{pg} / \mathrm{mL}$ to $354 \pm 21.5 \mathrm{pg} / \mathrm{mL}$ after TNF- $\alpha$ stimulation $(p<0.001)$ (Fig. 4). Treatment of TA cells with low dose of AZM $(4 \mu \mathrm{g} / \mathrm{mL})$ reduced the levels of IL-6 $(256 \pm 15.2 \mathrm{pg} / \mathrm{mL}, p=0.047)$ and IL-8 $(293 \pm 18.5$ $\mathrm{pg} / \mathrm{mL}, p=0.048)$ to some extent. However, the addition of the higher concentration of AZM $(8 \mu \mathrm{g} / \mathrm{mL})$ reduced IL-6



Figure 3. AZM inhibited TNF- $\alpha$-induced IL-6 release in TA cells from premature infants. IL- 6 was measured in the cell culture media after $18 \mathrm{~h}$ of stimulation with TNF- $\alpha(2 \mathrm{ng} / \mathrm{mL})$. TNF- $\alpha$ stimulation significantly increased the synthesis of IL-6 ( $p<0.001$ when compared with control group). In a dose-dependent manner, AZM suppressed the IL-6 released from TNF- $\alpha$ stimulated TA cells. Data represent mean \pm SEM of 11 individual experiments. ${ }^{* *} p<0.001$ compared with control group, $\dagger p<0.001$ compared with TNF- $\alpha$ treatment group and $* p<0.05$ compared with TNF- $\alpha$ treatment group. 


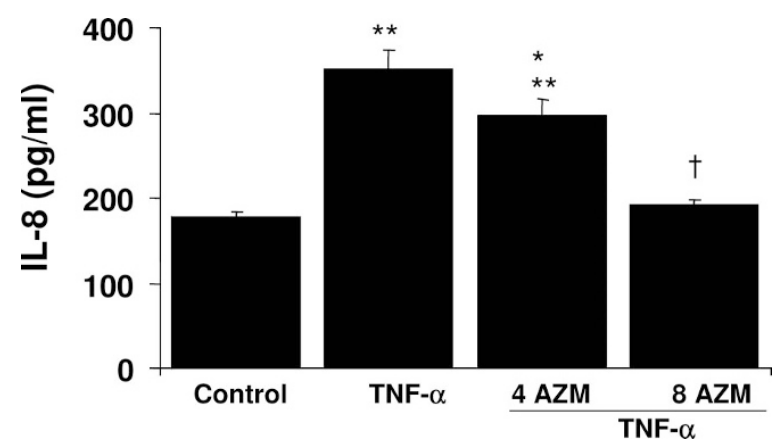

Figure 4. AZM inhibited TNF- $\alpha$-induced IL- 8 release in TA cells from premature infants. TNF- $\alpha$ stimulation $(2 \mathrm{ng} / \mathrm{mL})$ significantly increased the synthesis of IL-8 ( $p<0.001$ when compared with control group). AZM, in a dose-dependent manner, suppressed the IL- 8 released from TNF- $\alpha$ stimulated TA cells. Data represent mean \pm SEM of 11 individual experiments. $* * p<$ 0.001 compared with control group, $\dagger p<0.001$ compared with TNF- $\alpha$ treatment group and $* p<0.05$ compared with TNF- $\alpha$ treatment group.

$(160 \pm 6.5 \mathrm{pg} / \mathrm{mL} . p<0.001)$ and IL-8 $(190 \pm 5.8 \mathrm{pg} / \mathrm{mL}$, $p<0.001)$ to levels similar to control.

\section{DISCUSSION}

The NF- $\kappa \mathrm{B}$-dependent transcription of pro-inflammatory mediators may have a central role in lung inflammation in premature neonates with respiratory distress. This study demonstrates that the transcription factor NF- $\kappa \mathrm{B}$ is activated in the cellular component of TA samples from ventilated premature infants. It is known that pro-inflammatory cytokines TNF- $\alpha$, IL-1 $\beta$, IL-6 and IL-8 are markedly elevated in TA from premature neonates with RDS who subsequently develop BPD (12-14). Cao et al. (6) reported the activation of NF- $\kappa \mathrm{B}$ in alveolar macrophages of ventilated preterm infants. The activation of NF- $\kappa$ B correlated with the levels of IL- $1 \beta$ and IL-8 in TA. Similarly, Cheah et al. (15) obtained 172 TA samples from 59 ventilated infants, two third of whom showed NF- $\kappa$ B activation in pulmonary neutrophils and macrophages on at least one occasion. The infants who had activated NF- $\kappa \mathrm{B}$ showed elevated TNF- $\alpha$ concentrations in their TA and required a longer duration of mechanical ventilation. More recently, Bourbia et al. (7) reported that the activation of $\mathrm{NF}-\kappa \mathrm{B}$ in TA cells from preterm infants correlated with the cell count, IL-8, and fraction of inspired oxygen. The activation of NF- $\kappa \mathrm{B}$ was increased in TA cells of preterm infants who either died or developed BPD when compared with those without BPD. Overall, the existing literature supports the finding that NF- $\kappa \mathrm{B}$ is activated in the cellular component of TA from ventilated premature infants. The reason for the activation of NF- $\kappa \mathrm{B}$ in premature infants is not known but it may be possible that an underlying inflammation or cellular stress would trigger NF- $\kappa \mathrm{B}$ translocation into the nucleus. It is known that infection (chorioamnionitis), oxidative stress, and ventilator-associated lung injury cause the activation of $\mathrm{NF}-\kappa \mathrm{B}(1,15)$. Hence, increased mortality and greater incidence of BPD in preterm infants exposed to chorioamnionitis, oxidative stress, and mechanical ventilation are possibly mediated by the activation of NF- $\kappa \mathrm{B}$ and subsequent release of pro-inflammatory mediators.
Suppressing NF- $\kappa$ B dependent pro-inflammatory mediators by inhibiting the activation of NF- $\kappa \mathrm{B}$ is a novel approach to decrease lung inflammation and the subsequent development of BPD in premature infants. We recently reported that dexamethasone therapy suppresses the activation of NF- $\kappa \mathrm{B}$ in pulmonary leukocytes from premature infants (8). Dexamethasone therapy not only suppressed the expression of NF- $\kappa \mathrm{B}$ but also decreased the concentrations of pro-inflammatory mediators in ventilated preterm infants. Decreased activation of NF- $\kappa \mathrm{B}$ was also associated with clinical improvement in premature infants as reflected by lower ventilatory support. However, steroid therapy in premature infants has been reported to be associated with intestinal perforation, intestinal bleeding, developmental delay, and cerebral palsy $(9,10)$. Recently, the AAP issued a strong statement against steroid use in premature infants for the prevention of BPD (11). In addition, oxidative or mechanical stress may decrease the anti-inflammatory effect of glucocorticoids in alveolar macrophages by modulating its receptors or by other mechanisms involving the recruitment of histone deacetylase- 2 protein in the transrepression complex $(1,16-18)$. There is a need to find a safe and effective anti-inflammatory therapy as an alternative to steroid use in premature ventilated infants.

Azithromycin, a macrolide antibiotic and an immunomodulator, displays anti-inflammatory effects that may be useful in chronic inflammatory lung diseases. Clinical studies have shown that macrolides have beneficial effects in diffuse panbronchiolitis (19), bronchial asthma (20), bronchiectasis (21), bronchiolitis obliterans syndrome (22), and cystic fibrosis (23). Furthermore, erythromycin suppresses NF- $\kappa \mathrm{B}$ activation and inhibits the production of IL- 6 and IL-8 in human bronchial epithelial cells $(24,25)$. In animal models, AZM attenuates the lipopolysaccharide (LPS)-induced increase in plasma TNF- $\alpha$ concentrations and improves inflammatory markers (total cell count, neutrophil percentage and macrophage inflammatory protein-2) in bronchoalveolar lavage fluid (26).

To our knowledge, this is the first study demonstrating the inhibition of the activation of NF- $\kappa$ B by AZM in premature infants. AZM not only decreased the TNF- $\alpha$ stimulated activation of NF- $\kappa$ B by approximately $52 \%$ but also suppressed the synthesis of NF- $\kappa \mathrm{B}$-dependant pro-inflammatory cytokines (IL-6 and IL-8). We chose the concentrations of AZM (4 $\mu \mathrm{g} / \mathrm{mL}$ and $8 \mu \mathrm{g} / \mathrm{mL}$ ) based on pharmacokinetic studies performed in adults. After standard doses, the levels of AZM in adult lungs range between $4.0 \mu \mathrm{g} / \mathrm{g}$ and $9.6 \mu \mathrm{g} / \mathrm{g}(27,28)$. To our knowledge, the concentration of AZM in the lungs of premature infants has not been studied. However, by extrapolating adult data in premature infants, the standard dose $(5-10 \mathrm{mg} / \mathrm{kg} / \mathrm{d})$ may lead to sufficiently high concentrations of AZM in the lungs of premature infants to suppress the activation of NF- $\kappa \mathrm{B}$ and the synthesis of pro-inflammatory cytokines.

In the present study, we found that stimulation of TA cells by TNF- $\alpha$ increased the activation of NF- $\kappa \mathrm{B}$ as indicated by the degradation of $\mathrm{I} \kappa \mathrm{B}-\alpha$ in the cytoplasm and increased $\mathrm{NF}-\kappa \mathrm{B}$ binding activity in the nuclear extract. AZM at a higher dose inhibited TNF- $\alpha$-induced degradation of I $\kappa \mathrm{B}-\alpha$ in TA cells obtained from preterm infants. The molecular mech- 
anism of NF- $\kappa$ B inhibition by AZM is unknown but there are conflicting reports demonstrating the $\mathrm{I} \kappa \mathrm{B}$ kinase-dependent and independent mechanisms for inhibition of NF- $\kappa$ B activation by macrolide antibiotics $(24,29,30)$. Moreover, our own data showed that the TNF- $\alpha$-induced I $\kappa \mathrm{B}-\alpha$ degradation (which occurs mainly via I $\kappa$ B kinase beta or IKK2-dependent mechanism) is blocked by AZM in TA cells, thereby suggesting that the AZM inhibited NF- $\kappa \mathrm{B}$ activation by $\mathrm{I} \kappa \mathrm{B}-\alpha$ degradation.

The lower concentration of AZM was not effective in suppressing the activation of NF- $\kappa \mathrm{B}$ and the release of IL-6 and IL-8. Cigana et al. (31) also reported similar dose dependant suppression of IL-8 by AZM in cystic fibrosis airway epithelial cells. In their study, concentrations of $0.125,0.5$ and $2 \mu \mathrm{g} / \mathrm{mL}$ of AZM were unable to suppress IL-8 production but increasing the AZM concentration to $8 \mu \mathrm{g} / \mathrm{mL}$ reduced IL-8 synthesis by $50 \%$. In this current study, the higher level of AZM $(8 \mu \mathrm{g} / \mathrm{mL})$ reduced the activation of NF- $\kappa$ B and synthesis of IL- 6 and IL- 8 by TNF- $\alpha$ stimulated TA cells to a level similar to the control group (unstimulated TA cells). The concentration of TNF- $\alpha$ is increased very early (on D 2-3) in the TA from premature infants who subsequently developed BPD (14). Because TNF- $\alpha$ plays a major role as a stimulator of chemokines in the lungs of premature neonates, we speculate that the early treatment with AZM may provide antiinflammatory protection by suppressing the activation of $\mathrm{NF}-\kappa \mathrm{B}$ and reducing the synthesis of NF- $\kappa \mathrm{B}-$ dependant proinflammatory mediators. Infection and colonization of the respiratory tract with ureaplasma and Mycoplasma may also trigger a vigorous pro-inflammatory response in the lungs and increase the risk for the development of BPD in preterm infants (32). Ureaplasma urealyticum increases the activation of NF- $\kappa \mathrm{B}$ in alveolar macrophages (33). AZM as an antibiotic and anti-inflammatory agent may decrease lung inflammation by suppressing ureaplasma-induced NF- $\kappa \mathrm{B}$ activation and cytokine production in premature infants.

There are no published data evaluating the safety of AZM in term or preterm infants. The possible side effects of AZM in premature infants could include the following: feeding intolerance, infections, cardiac arrhythmias and hypertrophic pyloric stenosis. Widespread use of AZM in premature infants may also induce bacterial resistance. AZM therapy, by inhibiting NF- $\kappa$ B activation and the release of inflammatory mediators, could alter innate immune response to pulmonary infection in premature infants. In vivo studies are required to evaluate the side effects of multi-dose, systemic AZM therapy in preterm infants.

The current study was performed on mixed TA cells and does not indicate the effect of AZM on the individual types of TA cells. However, the predominant cells in TA are neutrophils and alveolar macrophages. We, and others, have shown that NF- $\kappa \mathrm{B}$ is localized and activated in both the neutrophils and alveolar macrophages in TA obtained from preterm infants $(8,15)$.

In summary, the present study demonstrates that AZM suppresses the NF- $\kappa \mathrm{B}$ activation in TA cells from preterm ventilated infants. Suppression of NF- $\kappa$ B activation was also associated with decreased synthesis of NF- $\kappa \mathrm{B}$-dependent pro- inflammatory mediators. Further studies are needed on the safety and efficacy of AZM before it can be used as an alternative to steroids in the treatment of acute lung injury and prevention of BPD in premature infants.

Acknowledgments. The authors thank Charlene Martin, R.N., Jane Hasson, R.N., Valerie Gibson, R.N., and Lois Meyer, R.N., for their help in screening the babies for enrollment and collecting the tracheal aspirates. We also thank Kee Pyon, Ph.D., for her help in analyzing the data and reviewing the manuscript.

\section{REFERENCES}

1. Rahman I, MacNee W 1998 Role of transcription factors in inflammatory lung diseases. Thorax 53:601-612

2. Blackwell TS, Christman JW 1997 The role of nuclear factor-kappa B in cytokine gene regulation. Am J Respir Cell Mol Biol 17:3-9

3. Christman JW, Lancaster LH, Blackwell TS 1998 Nuclear factor kappa B: a pivotal role in the systemic inflammatory response syndrome and new target for therapy. Intensive Care Med 24:1131-1138

4. Christman JW, Sadikot RT, Blackwell TS 2000 The role of nuclear factor-kappa B in pulmonary diseases. Chest 117:1482-1487

5. Schwartz MD, Moore EE, Moore FA, Shenkar R, Moine P, Haenel JB, Abraham E 1996 Nuclear factor-kappa B is activated in alveolar macrophages from patients with acute respiratory distress syndrome. Crit Care Med 24:1285-1292

6. Cao L, Liu C, Cai B, Jia X, Kang L, Speer CP, Sun B 2004 Nuclear factor-kappa B expression in alveolar macrophages of mechanically ventilated neonates with respiratory distress syndrome. Biol Neonate 86:116-123

7. Bourbia A, Cruz MA, Rozycki HJ 2006 NF-kappaB in tracheal lavage fluid from intubated premature infants: association with inflammation, oxygen and outcome. Arch Dis Child Fetal Neonatal Ed 91:F36-F39

8. Aghai ZH, Kumar S, Farhath S, Kumar MA, Saslow J, Nakhla T, Eydelman R, Strande L, Stahl G, Hewitt C, Nesin M, Rahman I 2006 Dexamethasone suppresses expression of nuclear factor-kappab in the cells of tracheobronchial lavage fluid in premature neonates with respiratory distress. Pediatr Res 59:811-815

9. Halliday HL, Ehrenkranz RA, Doyle LW. 2003 Early postnatal (<96 hours) corticosteroids for preventing chronic lung disease in preterm infants. Cochrane Database Syst Rev: CD001146

10. Halliday HL, Ehrenkranz RA, Doyle LW. 2003 Moderately early (7-14 days) postnatal corticosteroids for preventing chronic lung disease in preterm infants. Cochrane Database Syst Rev: CD001144

11. Committee on Fetus and Newborn 2002 Postnatal corticosteroids to treat or prevent chronic lung disease in preterm infants. Pediatrics 109:330-338

12. Munshi UK, Niu JO, Siddiq MM, Parton LA 1997 Elevation of interleukin-8 and interleukin-6 precedes the influx of neutrophils in tracheal aspirates from preterm who develop bronchopulmonary dysplasia. Pediatr Pulmonol 24:331-336

13. Tullus K, Noack GW, Burman LG, Nilsson R, Wretlind B, Brauner A 1996 Elevated cytokines levels in tracheobronchial aspirates fluids from ventilator treated neonates with BPD. Eur J Pediatr 155:112-116

14. Jonsson B, Tullus K, Brauner A, Lu Y, Noack G 1997 Early increase of TNF alpha and IL-6 in tracheobronchial aspirate fluid indicator of subsequent chronic lung disease in preterm infants. Arch Dis Child Fetal Neonatal Ed 77:F198-F201

15. Cheah FC, Winterbourn CC, Darlow BA, Mocatta TJ, Vissers MC 2005 Nuclear factor kappaB activation in pulmonary leukocytes from infants with hyaline membrane disease: associations with chorioamnionitis and Ureaplasma urealyticum colonization. Pediatr Res 57:616-623

16. Kirkham P, Rahman I 2006 Oxidative stress in asthma and COPD: antioxidants as a therapeutic strategy. Pharmacol Ther 111:476-494

17. Culpitt SV, Rogers DF, Shah P, De Matos C, Russell RE, Donnelly LE, Barnes PJ 2003 Impaired inhibition by dexamethasone of cytokine release by alveolar macrophages from patients with chronic obstructive pulmonary disease. Am J Respir Crit Care Med 167:24-31

18. Culpitt SV, Maziak W, Loukidis S, Nightingale JA, Mathews JL, Barnes PJ 1999 Effect of high dose inhaled steroid on cells, cytokines, and proteases in induced sputum in chronic obstructive pulmonary disease. Am J Respir Crit Care Med 160:1635-1639

19. Kadota J, Sakito O, Kohno S, Sawa H, Mukae H, Oda H, Kawakami K, Fukushima K, Hirtani K, Hara K 1993 A mechanism of erythromycin treatment in patients with diffuse panbronchiolitis. Am Rev Respir Dis 147:153-159

20. Amayasu H, Yoshida S, Ebana S, Yamamoto Y, Nishikawa T, Shoji T, Nakagawa H, Hasegawa H, Nakabayashi M, Ishizaki Y 2000 Clarithromycin suppresses bronchial hyperresponsiveness associated with eosinophilic inflammation in patients with asthma. Ann Allergy Asthma Immunol 84:594-598

21. Tsang KW, Ho PI, Chan KN, Ip MS, Lam WK, Ho CS, Yuen KY, Ooi GC, Amitani R, Tanaka E 1999 A pilot study of low-dose erythromycin in bronchiectasis. Eur Respir J 13:361-364

22. Gerhardt SG, McDyer JF, Girgis RE, Conte JV, Yang SC, Orens JB 2003 Maintenance azithromycin therapy for bronchiolitis obliterans syndrome: results of a pilot study. Am J Respir Crit Care Med 168:121-125 
23. Clement A, Tamalet A, Leroux E, Ravilly S, Fauroux B, Jais JP 2006 Long term effects of azithromycin in patients with cystic fibrosis: a double blind, placebo controlled trial. Thorax 61:895-902

24. Desaki M, Takizawa H, Ohtoshi T, Kasama T, Kobayashi K, Sunazuka T, Omura S, Yamamoto K, Ito K 2000 Erythromycin suppresses nuclear factor-kappaB and activator protein-1 activation in human bronchial epithelial cells. Biochem Biophys Res Commun 267:124-128

25. Takizawa H, Desaki M, Ohtoshi T, Kikutani T, Okazaki H, Sato M, Akiyama N, Shoji S, Hiramatso K, Ito K 1995 Erythromycin suppresses interleukin 6 expression by human bronchial epithelial cells: a potential mechanism of its anti-inflammatory action. Biochem Biophys Res Commun 210:781-786

26. Ivetic Tkalcevic V, Bosnjak B, Hrvacic B, Bosnar M, Marjanovic N, Ferencic Z, Situm K, Culic O, Parnham MJ, Erakovic V 2006 Anti-inflammatory activity of azithromycin attenuates the effects of lipopolysaccharide administration in mice. Eur J Pharmacol 539:131-138

27. Di Paolo A, Barbara C, Chella A, Angeletti CA, Del Tacca M 2002 Pharmacokinetics of azithromycin in lung tissue, bronchial washing, and plasma in patients given multiple oral doses of 500 and $1000 \mathrm{mg}$ daily. Pharmacol Res 46:545-550
28. Nightingale CH 1997 Pharmacokinetics and pharmacodynamics of newer macrolides. Pediatr Infect Dis J 16:438-443

29. Blau H, Klein K, Shalit I, Halperin D, Fabian I 2007 Moxifloxacin but not ciprofloxacin or azithromycin selectively inhibits IL-8, IL-6, ERK1/2, JNK, and NF-kappaB activation in a cystic fibrosis epithelial cell line. Am J Physiol Lung Cell Mol Physiol 292:L343-L352

30. Desaki M, Okazaki H, Sunazuka T, Omura S, Yamamoto K, Takizawa H 2004 Molecular mechanisms of anti-inflammatory action of erythromycin in human bronchial epithelial cells: possible role in the signaling pathway that regulates nuclear factor-kappaB activation. Antimicrob Agents Chemother 48:1581-1585

31. Cigana C, Nicolis E, Passeto M, Assael BM, Mellotti P 2006 Anti-inflammatory effects of azithromycin in cystic fibrosis airway epithelial cells. Biochem Biophys Res Commun 350:977-982

32. Li YH, Yan ZQ, Jensen JS, Tullus K, Brauner A 2000 Activation of nuclear factor kappaB and induction of inducible nitric oxide synthase by Ureaplasma urealyticum in macrophages. Infect Immun 68:7087-7093

33. Schelonka RL, Waites KB 2007 Ureaplasma infection and neonatal lung disease. Semin Perinatol 31:2-9

\section{Erratum}

In the article, "Novel kinetic insights into treatment of unconjugated hyperbilirubinemia: phototherapy and orlistat treatment in Gunn rats" by Frans J.C. Cuperus et al. (Pediatr Res 59:506-512), the authors report that the fractional turnover of ${ }^{3} \mathrm{H}$-unconjugated bilirubin was erroneously calculated from $\log 10$ instead of $\ln$ (natural logarithmic) semi-logarithmic plots of the specific activity. The reported fractional turnover (Table 2, Fig. 3 and Fig. 4) and total turnover (Table 2) should therefore be multiplied with 2.3 in all experimental groups. As a result, the net transmucosal flux of unconjugated bilirubin (UCB; Fig. 4), calculated as the difference between fractional turnover and fractional biliary excretion, increases in all experimental groups. Corrected information is presented in Table 1 of this erratum.

The corrected information does not affect the main findings of the study. Significance levels and the linear relation (Table 2 and Fig. 3) are unaltered, and the interpretation of data in these figures remains unchanged. The corrected net transmucosal flux (Fig. 4) indicates transmucosal UCB excretion into the intestinal lumen in all experimental groups, rather than only in the orlistat- and the combined orlistat and phototherapy group. This implies that, as indicated by Schmid and Hammaker (J Clin Invest 42:1720), under control conditions, transmucosal UCB excretion is an important secretory pathway in Gunn rats. The study shows that this secretory pathway is enhanced by orlistat treatment.

Table 1. Corrected fractional turnover and total turnover of ${ }^{3} \mathrm{H}$-bilirubin and net transmucosal UCB flux

\begin{tabular}{|c|c|c|c|c|}
\hline & Controls $(n=6)$ & Orlistat $(n=5)$ & PT $(n=4)$ & Orlistat + PT $(n=4)$ \\
\hline Fractional turnover ${ }^{3} \mathrm{H}-\mathrm{UCB}(\% / \mathrm{h})$ & $\begin{array}{l}1.36 \pm 0.53 \\
2.10 \pm 0.47 \dagger\end{array}$ & $2.30 \pm 0.15^{*}$ & $2.97 \pm 0.29 \S$ & \\
\hline Total turnover bilirubin (nmol/h per $100 \mathrm{~g} \mathrm{BW})$ & $\begin{array}{l}69.1 \pm 14.9 \\
79.5 \pm 12.6\end{array}$ & $84.3 \pm 11.1$ & $84.3 \pm 7.6$ & \\
\hline $\begin{array}{l}\text { Net transmucosal UCB flux } \\
(\% \text { of exchangeable bilirubin pool excreted } / \mathrm{h})\end{array}$ & $0.74 * *$ & $1.42 * *$ & $1.27 * *$ & $2.28 * *$ \\
\hline
\end{tabular}

Data represent mean \pm SD. For calculation of fluxes see Methods section.

$* p<0.05$, II $p=0.058, \S p<0.001$ compared with controls.

$\dagger p<0.05$ compared with orlistat $+\mathrm{PT}$.

** The estimated net transmucosal flux is directed from the blood into the intestinal lumen in all experimental groups. This is the corrected flux [E] from Figure 4 in the original paper. 